\title{
Attitudes Regarding Action Learning: Undergraduate Vs. Graduate Business Students
}

Alvin Rosenstein, Adelphi University, USA

Allan Ashley, Adelphi University, USA

Rakesh Gupta, Adelphi University, USA

Kristin Ulin, Adelphi University, USA

\begin{abstract}
Previous research in our Action Learning Program demonstrated that although undergraduates preferred the Action Learning mode to the traditional lecture and discussion mode of instruction, they missed the familiar structure of the more traditional pedagogy. Consequently increased structure was implemented in both an undergraduate and graduate marketing course utilizing the Action Learning mode. Students' reactions to the modified courses were assessed. Although both undergraduate and graduate approval of these courses was high, the reasons for the approval were quite different. The undergraduates placed significant emphasis on the pedagogical issues while graduate students focused on skills they obtained in the course and the fact that the course related to their career/job. These results have had significant impact on the redesign of both courses.
\end{abstract}

Keywords: action learning, experiential learning, pedagogical techniques, pedagogy

\section{INTRODUCTION}

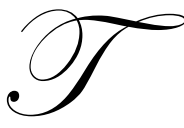

his is the fourth in a series of articles and conference presentations that interested faculty at the Adelphi University School of Business have undertaken in exploring the utility of Action Learning for the teaching both undergraduate and graduate business students.

To briefly review its philosophical basis, Action Learning is grounded in the pragmatic functional philosophy of John Dewey, who critiqued traditional, classroom-based education and maintained that experience, learning and development are interconnected. He argued that students achieve the greatest and most durable mastery of a discipline only when they are provided the opportunity to put into real world practice the principles they learn from the text and in the classroom (Dewey 1915).

Believing this, he stressed that school must provide opportunity for the interplay of thinking and doing in a manner that replicates the challenges that the student will face in the real world. He practiced what he preached and in so doing embraced and popularized the practice of student teaching, a hallmark of contemporary teacher education.

Others, including the authors, have applied his Action Learning philosophy to their own disciplines.

As implemented at Adelphi University's School of Business, Action Learning differs in several significant ways from more traditional learning aids, such as case studies and business games, in which students analyze and react to prepared material presented within the context of a course. Typically, the class is brought in as "consultant," at the invitation of individuals associated with a business or non-profit institution, seeking competent professional guidance at a minimal cost. The problem is real and there is no guarantee of a pat answer or success; 
the instructor screens and structures the problem so that it is appropriate to the capabilities of the class working under the instructor's guidance. The students therefore learn the discipline, as it is practiced "in vitro," with all the attendant haphazard circumstances and difficulties that arise within this context. This generally enhances their understanding of both the "rules" of the discipline and the need for these rules.

Previous research in our Action Learning program has demonstrated that both undergraduates and graduate students preferred the Action Learning mode (of teaching Marketing), to the more traditional lecture and discussion mode of instruction. However, the efficacy of Action Learning seemed more pronounced for graduate than for undergraduate students. The hypothesis generated from the data was that the undergraduates, while also preferring the Action Learning mode, missed the familiar structure of traditional pedagogy, more so than did the graduate students (Gupta et al. 2005).

Subsequent qualitative research then was conducted in order to enhance our understanding of the pedagogical priorities of undergraduate business students and how Action learning might be tailored to meet the priorities (Rosenstein et al. 2006). The major findings of this research are summarized below.

1. This qualitative research confirmed undergraduate student preference for the Action Learning mode of instruction over the Traditional lecture and discussion method.

2. When asked for the reasons for their preference for Action Learning over the Traditional teaching mode, the students primarily focused on the value they found in the "hands-on" approach, which they felt was superior to the Traditional mode in facilitating initial learning and/or recall.

3. They not only felt they learned more from Action Learning, but they also indicated they actually found the Action Learning classes enjoyable. In fact, when the students were probed for why they indicated that if they "had to do it over again," they still would take the course, about half used words such as "liked/enjoyed," "interesting" and "fun" to describe their reactions.

4. When asked how the course might be improved, a desire for greater structure was voiced by roughly one quarter of the students. This is consistent with the hypothesis noted above that while undergraduates prefer the Action Learning mode, they miss the familiar structure of the more traditional pedagogy.

Following completion of the analysis described above, increased structure was implemented in both the undergraduate and graduate courses utilizing Action Learning. The increased structure primarily consisted of more detailed "how to" hand-outs and "template" examples of projects completed by past students.

\section{RESEARCH OBJECTIVE}

The current qualitative research is intended to assess student reactions to undergraduate and graduate marketing (Marketing Research) courses and to further enhance our understanding of how we might best meet their pedagogical priorities.

\section{METHOD}

At the last class of the Fall 2005 semester, students in the undergraduate $(\mathrm{N}=21)$ and graduate $(\mathrm{N}=14)$ Marketing Research courses completed anonymous, self-administered questionnaires assessing their reactions to these courses. As indicated above, these courses, taught in the Action Learning mode, had been modified on the basis of prior student feedback to incorporate increased structure. 


\section{RESULTS}

Table 1

Responses to the question: "If you had to do it over again, would you take the course?"

\begin{tabular}{|c|c|c|c|c|c|}
\hline Graduate & Frequency & \% & Undergraduate & Frequency & \% \\
\hline Definitely & 11 & 79 & Definitely & 17 & 81 \\
\hline Probably & 3 & 21 & Probably & 4 & 19 \\
\hline Undecided & 0 & 0 & Undecided & 0 & 0 \\
\hline Probably Not & 0 & 0 & Probably Not & 0 & 0 \\
\hline Definitely Not & 0 & 0 & Definitely Not & 0 & 0 \\
\hline
\end{tabular}

Table 2

Responses to the question: "Why do you say this (would take course again)?"

\begin{tabular}{|c|c|c|c|}
\hline Graduate & \% & Undergraduate & \% \\
\hline $\begin{array}{c}\text { I Learned How To Conduct } \\
\text { Marketing Research }\end{array}$ & 50 & Well defined Course & 38 \\
\hline $\begin{array}{c}\text { Course Was Related To My } \\
\text { Career/Job }\end{array}$ & 14 & $\begin{array}{c}\text { Course Used Action } \\
\text { Learning } \\
\text { Methods/Techniques }\end{array}$ & 33 \\
\hline Enjoyed Project & 14 & Excellent Professor & 29 \\
\hline Understanding Professor & 14 & & \\
\hline No Answer & 8 & & \\
\hline
\end{tabular}

Table 3

Responses to the question: "Would you say this course is More Worthwhile, or Less Worthwhile, or Neither More nor Less Worthwhile" than other courses you have taken?"

\begin{tabular}{|c|c|c|c|c|c|}
\hline Graduate & Frequency & \% & Undergraduate & Frequency & \% \\
\hline More Worthwhile & 12 & 86 & More Worthwhile & 18 & 86 \\
\hline Less Worthwhile & 0 & 0 & Less Worthwhile & 0 & 0 \\
\hline $\begin{array}{c}\text { Neither More Nor Less } \\
\text { Worthwhile }\end{array}$ & 2 & 14 & $\begin{array}{c}\text { Neither More Nor Less } \\
\text { Worthwhile }\end{array}$ & 3 \\
\hline
\end{tabular}

Table 4

Responses to the question: "Why do you consider this course more worthwhile than other business courses you have taken?"

\begin{tabular}{|c|c|c|c|}
\hline Graduate & \% & Undergraduate & \% \\
\hline $\begin{array}{c}\text { Course Was Related To My } \\
\text { Career/Job }\end{array}$ & 43 & $\begin{array}{c}\text { I Learned A Lot About } \\
\text { Marketing Research }\end{array}$ & 19 \\
\hline $\begin{array}{c}\text { I Learned A Lot About } \\
\text { Marketing Research }\end{array}$ & 21 & $\begin{array}{c}\text { Course Improved My } \\
\text { Marketing Research Skills }\end{array}$ & 14 \\
\hline No Answer & 21 & $\begin{array}{c}\text { I Liked Action Learning } \\
\text { Method Of Teaching }\end{array}$ & 10 \\
\hline $\begin{array}{c}\text { Good Classroom } \\
\text { Atmosphere }\end{array}$ & 8 & $\begin{array}{c}\text { Course Was Related To My } \\
\text { Career/Job }\end{array}$ & 10 \\
\hline All Courses Are Worthwhile & 7 & $\begin{array}{c}\text { Some Material/Workload As } \\
\text { Other Marketing Courses }\end{array}$ & \multicolumn{2}{|c|}{10} \\
\hline
\end{tabular}




\section{DISCUSSION OF THE FINDINGS}

1. The undergraduate and graduate students indicated comparable levels of high approval to the modified Action Learning courses. All students in both courses indicated that if they had to do over, they either "definitely" (roughly 8 out of 10 for both) or "probably" would take these courses again (Table 1).

2. Although the undergraduate and graduate students both expressed high levels of course approval, as examination of Table 2 reveals the reasons for these responses were somewhat different. When additionally asked why they would take the course again, undergraduates placed greatest emphasis on pedagogical issues such as "Well Defined Course" (38\%), "Course Used Action Learning Methods/Techniques" (33\%), and even "Excellent Professor" (29\%). Significantly, this is consistent with the past research. In contrast, the graduate students focused more on skills acquisition (50\%) as the primary reason for taking the course.

3. They also responded in a similar manner when asked if the course was "more worthwhile", "neither more nor less worthwhile", or "less worthwhile" that other business courses they had taken. Eight-six per cent of the students in both classes responded "more worthwhile," while none said "less worthwhile" (Table 3).

4. When asked why the course was more worthwhile than other business courses they had taken, the graduate students' primary response $(43 \%)$ was that the course was related to their career and job (i.e., the graduate projects generally were related to their work-place issues). Here, the undergraduates gave greater emphasis to what they had learned about marketing research (38\%) and skills acquisition (19\%).

\section{PEDAGOGICAL IMPLICATIONS OF THE FINDINGS}

1. Both undergraduate and graduate students give high ratings to the Action Learning courses. They enjoy and appreciate both the "learning by doing" pedagogical techniques employed and the knowledge and skills acquired.

2. However, it is important that courses in the Action Learning mode provide sufficient course structure to ensure that (1) the students are able to perform the assigned tasks correctly, and (2) that the professor can identify and have the student promptly remedy any incorrect or inadequate performance.

3. While important for all students, such structure is especially important for undergraduates, who are less able than their graduate counterparts to handle ambiguity.

4. Action Learning courses are especially good vehicles for meeting graduate students' high priority for skills acquisition and for relating course work to job and career.

\section{AUTHOR INFORMATION}

Alvin Rosenstein is Professor of Marketing at Adelphi University's School of Business. He teaches Marketing Research, Marketing Strategy, New Product Development, and Consumer Behavior - all taught in the Action Learning mode.

Rakesh Gupta is Interim Dean of the School of Business at Adelphi University. He earned an MBA from Baruch College and was an electrical engineer. His research interests are in Strategic Management, with a focus on pedagogy of business ethics, and management of technology.

Allan Ashley is Professor of Decision Sciences, and Chairman of the Department of Management, Marketing and Decision Sciences at Adelphi University. His research interests include channel coordination and bargaining in supply chain models, and corporate and educational models that involve leadership, innovation, technology, and ethics.

Kristin Ulin attended Adelphi University for both BBA and MBA degrees in Management. She was awarded a graduate research assistantship and did research on Action Learning. She is a Guest Service Manager at Elizabeth Arden. 


\section{REFERENCES}

1. Dewey, John (1915). The School and Society. Chicago: University of Chicago Press.

2. Gupta, R., Ashley, A. \& Rosenstein, A. (2005). "Implementing Action Learning in Marketing Research Courses." Proceedings of Northeast Decision Sciences Institute, May 2005.

3. Rosenstein, A., Gupta, R. \& Ashley, A. (2004). "Action Learning: A "New" Teaching Tool for Undergraduate Business Education." Journal of College Teaching and Learning, May 2004.

4. Rosenstein, A., Gupta, R. \& Ashley, A. (2006). "A Qualitative Exploration of Action Learning: Undergraduate Students' Attitudes.” Journal of College Teaching \& Learning, September 2006.

Please contact the authors for additional references.

\section{NOTES}


NOTES 